\title{
INTEGRASI LEMBAGA PENYELESAIAN SENGKETA ALTERNATIF DALAM \\ PROSES ACARA PERADILAN PERDATA: STUDI TENTANG PUTUSAN PENGADILAN YANG DI MEDIASI BERDASARKAN \\ PERMA NOMOR 1 TAHUN 2008
}

Oleh :

\author{
Anak Agung Ngurah Roy Sumardika ${ }^{1}$
}

\begin{abstract}
Mediation process means dispute resolution through negotiation process for obtaining a peace agreement between the parties by using a third party in settling the dispute. Article 130 $H I R / 154$ RBg determines peace efforts may use since the trial began before a judge hands down the dispute. Mediation as part of the Alternative Dispute Resolution is a process outside the court, but Indonesian Supreme Court Rules No. 1/2008 integrates it in the court proceedings and allows the mediation process at the level of legal remedy. So the problem investigated is the court decision remediated and the peace agreement mediation results. The method used normative legal research by Legislation Approach and to deepen the research study also use a Legal Concept Analysis Approach which is intended to establish a view and legal arguments in solving the problem at hand.

Case that has been decided by the courts is not possible to re-mediated. The mediation process at the level of legal remedy is contrary to the law, especially the provisions of Article 130 HIR / 154 RBg. Indonesian Supreme Court Rules as rules are hierarchically under the law $(H I R / R B g)$ not justified material being regulated substance exceeding material are governed by higher laws. So Indonesian Supreme Court Rules No. 1/2008 can not be a legal basis to regulate the integration of mediation into the docket particularly about mediation at the level of legal remedy because the principle of lex superiori derogat legi inferiori and the principle of lex specialis derogat legi generali not met.
\end{abstract}

Keywords : integration, mediation, legal remedy

\footnotetext{
${ }^{1}$ Mahasiswa Magister Ilmu Hukum Universitas Udayana, Denpasar, Bali. Alamat : Jl. Gunung Merapi 7D, Denpasar, e-mail: agungroyka@yahoo.com
} 


\section{PENDAHULUAN}

\section{Latar Belakang Masalah}

Sengketa bermula dari pertentangan atau perbedaan paham di dalam interaksi sosial di masyarakat. Perbedaan paham tersebut tidak akan tumbuh menjadi sebuah perselisihan bila yang dirugikan hanya mendiamkan rasa tidak puasnya/ kekecewaannya. Bila pihak yang dirugikan telah menyatakan rasa tidak puasnya atau kekecewaannya baik secara langsung kepada pihak yang dianggap sebagai penyebab kerugian/kepada pihak lain, maka perbedaan paham tersebut berubah menjadi sengketa. Dengan demikian mereka masuk ke dalam tahap mencari atau menginginkan penyelesaian.

Merupakan hal yang wajar apabila mereka mengalami pertikaian/konflik/ sengketa (sebagai akibat perbedaan kepentingan di antara sesama mereka). Sengketa pada hakekatnya merupakan salah satu bentuk interaksi sosial dalam kehidupan bermasyarakat dimana sengketa dapat dikondisikan sebagai situasi duapihak/lebih dihadapkan pada perbedaan pendapat/ kepentingan. $^{2}$

Beraneka ragam cara dan kreativitas manusia dalam menyelesaikan perbedaan dan setiap cara maupun bentuk penyelesaian yang dipilih pada prinsipnya memiliki tujuan yang

\footnotetext{
${ }^{2}$ Tim Penyusun Pusat Bahasa, 2008. Kamus Bahasa Indonesia, Departemen Pendidikan Nasional, Jakarta. hal. 1413.
}

sama, yaitu mencari solusi atau penyelesaian untuk menghentikan perbedaan kepentingan yang ada (sengketa). Pola penyelesaian sengketa mengandung dua prinsip koreksi yaitu $^{3}$ :

1. Pola koreksi pribadi yang kemudian disebut sebagai prinsip penyelesaian dengan cara memutus (ajudikasi), dan

2. Pola koreksi bersama yang disebut prinsip penyelesaian perdamaian (non ajudikasi).

Dalam pergaulan hidup masyarakat, di bidang perdagangan, telah berkembang penyelesaian sengketa di luar pengadilan yang dikenal dengan sebutan Alternative Dispute Resolution (ADR). Penyelesaian sengketa di luar pengadilan adalah cara penyelesaian selain litigasi. Dengan keluarnya UU No. 30/1999 tentang Arbitrase dan Alternatif Penyelesaian Sengketa (APS), cara penyelesaian perkara perdata bisa dilakukan di luar peradilan umum.

Penyelesaian sengketa dengan mediasi adalah memakai jasa pihak ketiga (seorang mediator) untuk menolong dua pihak yang berperkara di dalam menyelesaikan perkaranya. "In mediation, where conflict is bound to be high, one central problem is how the mediator can maintain a balance, a neutrality between (or

${ }^{3}$ Darmoko Yuti Witanto, 2011. Hukum Acara Mediasi, Dalam Perkara Perdata di Lingkungan Peradilan Umum dan Peradilan Agama Menurut PERMA No. 1 Tahun 2008 tentang Prosedur Mediasi di Pengadilan, Alfabeta, Bandung, hal. 6. 
among) the parties". 4

Penyelesaian sengketa dengan cara mediasi, telah diatur oleh MA melalui peraturan pelaksanaan dan pemberdayaan lembaga perdamaian sebagai penyelesaian sengketa alternatif pada pengadilan diantaranya, SE MA No. 1/2002 tentang Pemberdayaan Pengadilan Tingkat Pertama menerapkan lembaga damai serta Perma No. 2/2003 tentang Prosedur Mediasi di Pengadilan dan sekarang telah mengalami perubahan dengan dikeluarkan Perma No. 1/2008 tentang Prosedur Mediasi di Pengadilan.

Salah satu perubahan dalam Perma No. 1/2008 tentang Prosedur Mediasi di Pengadilan adalah diperkenankan melakukan mediasi pada tingkat upaya hukum terhadap perkara yang telah mendapat putusan hakim hasil pemeriksaan/pembuktian dalam persidangan dan telah ada penilaian serta pertimbangan hukum hakim terhadap perkara tersebut. MA sebagai badan peradilan tertinggi di Indonesia melalui Perma tersebut mengintensifkan upaya damai serta mewajibkan setiap perkara perdata yang diajukan ke pengadilan menempuh proses mediasi bahkan dengan ancaman batal demi hukum serta memberikan ruang yang lebih luas serta mendorong kepada para pihak

\footnotetext{
${ }^{4}$ John Michael Haynes, Gretchen L. Haynes and Larry Sun Fong, 2004. Mediation, Positive Conflict Management, State University of New York Press, p. 249.
}

untuk melakukan mediasi di semua tingkatan upaya hukum, baik di tingkat banding, kasasi maupun peninjauan kembali, hal tersebut dimaksudkan untuk memberikan kesempatan bagi para pihak yang beritikad baik untuk menempuh kembali proses perdamaian.

Sementara dalam hukum acara peradilan perdata berdasarkan pasal 130 HIR/154 RBg, hanya mengenal upaya perdamaian yang wajib dilakukan oleh hakim kepada para pihak pada saat sidang pertama kehadiran kedua belah pihak. Kewajiban yang diberikan undang-undang kepada Hakim Pemeriksa Perkara untuk mengupayakan perdamaian berlangsung sejak persidangan dimulai sampai sebelum putusan perkara tersebut diucapkan.

Gambaran keadaan di atas, menarik perhatian penulis untuk mengadakan penelitian mengenai terintegrasinya Lembaga Penyelesaian Sengketa Alternatif dalam proses beracara di peradilan perdata khususnya putusan pengadilan yang di mediasi berdasarkan Perma No. 1/2008, yang telah menimbulkan kekacauan/kekaburan dari aspek normatif dimana lembaga mediasi sebagai bagian dari Alternatif Penyelesaian Sengketa (Pasal 1 angka 10 jo. Pasal 6 ayat (1) UU No. 30/1999) yang prosesnya berada di luar pengadilan namun oleh Perma No. 1/2008 diiintegrasikan dalam proses beracara di pengadilan. Dengan masuknya mekanisme dari non litigasi (penyelesaian di luar 
pengadilan) ke ranah litigasi (pengadilan) tentu menimbulkan kerancuan pada aspek normatif yang patut diteliti karena tidak menutup kemungkinan timbulnya konflik norma ataupun inkonsistensi. Dari pemaparan latar belakang tersebut, selanjutnya dilakukan penelitian yang diberi judul:

"Integrasi Lembaga Penyelesaian Sengketa

Alternatif Dalam Proses Acara Peradilan Perdata: Studi Tentang Putusan Pengadilan Yang Di Mediasi Berdasarkan Perma Nomor 1 Tahun 2008”.

\section{Rumusan Masalah}

Berlandaskan pada latar belakang dan identifikasi permasalahan diatas, dapat dirumuskan permasalahan, apakah perkara yang sudah diputus oleh pengadilan masih dimungkinkan untuk di mediasi kembali?

\section{Tujuan Penelitian}

Penelitian ini bertujuan untuk memahami serta menganalisa aspek normatif dari pengintegrasian Lembaga Penyelesaian Sengketa Alternatif dalam proses beracara di peradilan perdata khususnya mengenai putusan pengadilan yang di mediasi berdasarkan Perma No. 1/2008.

\section{METODE PENELITIAN}

Metode Penelitan yang digunakan adalah metode penelitian hukum normatif untuk menemukan kebenaran berdasarkan logika keilmuan hukum dari pandang normatif. Dalam peneltian ini pendekatan terhadap isu mengenai terintegrasinya lembaga mediasi dalam proses acara peradilan perdata di tingkat upaya hukum digunakan Pendekatan Perundang-undangan (statute approach), untuk memperdalam kajian penelitian juga menggunakan Pendekatan Analisis Konsep Hukum (analitical \& conseptual approach) yang dimaksudkan untuk membangun pandangan dan argumentasi hukum dalam memecahkan masalah yang dihadapi.

\section{HASIL DAN PEMBAHASAN}

Sengketa di bidang hukum adalah sengketa yang menimbulkan akibat hukum, baik disebabkan adanya pelanggaran pada aturan positif atau disebabkan benturan kepentingan yang berhubungan dengan hak dan kewajiban seseorang yang diatur dalam peraturan hukum positif. ${ }^{5}$ Beraneka ragam cara dan kreativitas manusia dalam menyelesaikan sengketa dan setiap cara dan bentuk penyelesaian yang dipilih pada prinsipnya memiliki tujuan yang sama, yaitu mencari solusi atau penyelesaian untuk menghentikan sengketa yang terjadi.

Penyelesaian suatu sengketa dalam konteks hukum dapat dilakukan melalui pendekatan-pendekatan konsensus (non litigasi) maupun pendekatan ajudikatif

\footnotetext{
${ }^{5}$ Darmoko Yuti Witanto, op.cit. hal. 4.
} 
(litigasi). Di Indonesia dengan dikeluarkannya Perma No. 1/2008 tentang Prosedur Mediasi di Pengadilan maka mediasi sudah terintegrasi ke dalam proses persidangan di pengadilan, sehingga mediasi sudah menjadi bagian dari proses litigasi. Kehadiran Perma ini dimaksudkan untuk memberikan kepastian, ketertiban, serta membantu kelancaran dalam mendamaikan pihak yang berperkara menyelesaikan perkara di bidang perdata dengan cara mengintensifkan serta mengintegrasikan prosedur mediasi dalam beracara di pengadilan. Perma ini merupakan penjabaran dari lembaga perdamaian yang diatur oleh pasal $130 \mathrm{HIR} / 154 \mathrm{RBg}$.

Berdasarkan pasal 1 angka 7 Perma No. 1/2008 tentang Prosedur Mediasi di Pengadilan, menyatakan mediasi adalah proses penyelesaian perkara dengan cara perundingan guna mendapatkan kesepakatan damai bagi mereka yang berperkara dengan bantuan mediator. Selanjutnya yang dimaksud mediator berdasarkan pasal 1 angka 6 Perma No. 1/2008 adalah pihak ketiga yang tidak memihak yang membantu mereka yang berperkara dalam perundingan agar mendapatkan berbagai kemungkinan penyelesaian perkara tanpa mempergunakan cara memutus dalam menyelesaikan sebuah perkara. Dari kedua ketentuan itu menandakan bahwa mediasi adalah proses penyelesaian perkara dengan bantuan pihak ketiga sebagai mediator.

Mengacu pada ketentuan pasal 1 angka 6 dan 7 Perma No. 1/2008 diatas dapat disimpulkan bahwa mediasi mengandung beberapa unsur dan ciri pokok atau karakter umum. Unsur-unsur yang terkandung dalam proses mediasi, antara lain :

1. Mediasi merupakan penyelesaian perkara dengan prinsip sukarela (volunter) dalam perundingan perdamaian;

2. Pihak ketiga sebagai mediator bersifat membantu mendapatkan solusi penyelesaian;

3. Kehadiran pihak ketiga sebagai mediator harus mendapat persetujuan mereka yang berperkara;

4. Hadirnya pihak ketiga untuk membantu penyelesaian perkara tidak mempunyai kewenangan membuat suatu keputusan selama dalam perundingan;

5. Hasil akhir yang diharapkan para pihak adalah kesepakatan yang dapat diterima para pihak yang berperkara untuk mengakhiri sengketa yang terjadi.

Sedangkan ciri pokok atau karakter umum yang terdapat dalam mediasi adalah sebagai berikut :

1. Ada dua atau beberapa pihak yang bersengketa;

2. Menggunakan bantuan pihak ketiga (mediator);

3. Pihak ketiga bertujuan untuk membantu para pihak dalam menyelesaikan 
sengketa;

4. Penyelesaian dilakukan berdasarkan kesepakatan para pihak. $^{6}$

Kedudukan Perma No. 1/2008 dalam tata urutan perundang-undangan, menurut pasal 8 ayat (2) UU No. 12/2011 menyatakan jenis peraturan perundang-undangan selain yang dimaksud pada ketentuan pasal 7 ayat (1), diakui keberadaanya serta berkekuatan hukum mengikat sepanjang diperintahkan oleh aturan yang lebih tinggi atau dibuat atas dasar kewenangan. Pasal 18 UU No. 48/2009 tentang Kekuasaan Kehakiman menyatakan Kekuasaan Kehakiman dilaksanakan oleh MA dan Badan Peradilan lainnya dalam lingkup Peradilan Umum, Agama, Militer dan Perdilan Tata Usaha Negara serta sebuah Mahkamah Konstitusi.

MA adalah lembaga tertinggi yang memegang kekuasaan Kehakiman yang berwenang menjaga pelaksanaan tertib hukum pada empat lingkungan peradilan dibawahnya. Ketentuan pasal 79 UU No. 3/2009 tentang Perubahan Kedua UU No. 14/1985 tentang MA, dimana MA berwenang membuat aturan untuk melengkapi serta mengisi kekurangan/kekosongan hukum yang berkaitan dengan kelancaran proses peradilan. Dengan demikian ketentuan pasal 79 tersebutlah yang memberikan kewenangan kepada MA sesuai dengan fungsinya mengatur jalannya peradilan untuk

\footnotetext{
${ }^{6}$ Darmoko Yuti Witanto, op.cit. hal. 4.
}

menerbitkan Peraturan Mahkamah Agung (Perma). Kewenangan dimaksud guna memberikan aturan yang belum diatur dalam undang-undang berkaitan dengan kelancaran penyelenggaraan peradilan.

Mengingat pasal 8 ayat (1) dan (2)) pasal 8 ayat (1) dan (2)) UU No. 12/2011 yang menyatakan bahwa jenis peraturan perundang-undangan selain yang dimaksud pasal 7 ayat (1) diakui keberadaanya dan berkekuatan hukum mengikat sepanjang dibentuk oleh aturan yang lebih tinggi. Atas dasar tersebut maka Perma sebagai produk hukum dari Lembaga Tinggi Negara yang lex superior-nya adalah pasal 79 UU No. 3/2009 jelas diakui eksistensinya dan mempunyai kekuatan hukum mengikat. ${ }^{7}$

Perma adalah pelaksana dari ketentuan undang-undang (subordinat legislations) yang mendapatkan delegasi dari undang-undang (delegated legislations). Walaupun Perma mendapat delegasi dari undang-undang, kedudukan Perma tidaklah sama dengan undang-undang karena Perma diterbitkan guna memperlancar pelaksanaan tugas dan wewenang MA yang bersifat internal yaitu untuk mengisi atau melengkapi kekosongan aturan guna kelancaran penyelenggaraan peradilan sehingga penerbitan Perma No. 1/2008 hanyalah

\footnotetext{
${ }^{7}$ I Made Sukadana, 2012. Mediasi Peradilan, Mediasi Dalam Sistem Peradilan Perdata Indonesia Dalam Rangka Mewujudkan Proses Peradilan Yang Sederhana, Cepat dan Biaya Ringan, Prestasi Pustaka, Jakarta, hal. 136.
} 
peraturan pelaksana untuk menjalankan ketentuan hukum acara perdata ( $\mathrm{HIR} / \mathrm{RBg})$ yang berkaitan dengan mediasi. Sehingga apa yang diatur dalam Perma tidaklah diijinkan berlawanan/bertentangan dengan aturan yang lebih tinggi. Perma No. 1/2008 memberikan peluang atau kemungkinan bagi para pihak untuk menempuh proses mediasi tidak hanya pada tingkat pertama tetapi juga untuk tingkat banding, kasasi dan peninjauan kembali. Hal itu dinyatakan dalam ketentuan pasal 21 ayat (1) yang menyatakan bahwa, "Para pihak atas dasar kesepakatan mereka dapat menempuh upaya perdamaian terhadap perkara yang sedang dalam proses banding, kasasi, atau peninjauan kembali atau terhadap perkara yang sedang diperiksa pada tingkat banding, kasasi, atau peninjauan kembali sepanjang perkara tersebut belum diputus". Upaya perdamaian tersebut dijinkan untuk dilakukan dalam waktu 14 (empat belas) hari kerja semenjak hal tersebut disampaikan kepada Ketua Pengadilan Negeri. Selanjutnya Ketua Pengadilan Negeri akan memberitahukan hal tersebut kepada Ketua Pengadilan Tinggi atau Ketua MA akan keinginan pihak yang berperkara untuk melaksanakan perdamaian. Kalau perkaranya masih diperiksa pada tingkat banding, kasasi atau peninjauan kembali maka majelis hakim pemeriksa perkara akan menunda pemeriksaan guna memberi kesempakan para pihak berperkara menempuh perdamaian. Jika berkas perkara belum dikirim maka Ketua Pengadilan Negeri wajib menunda proses pengiriman berkas perkara.

Atas persetujuan para pihak upaya perdamaian tersebut dapat dilaksanakan di pengadilan tingkat pertama atau tempat lain sesuai keinginan para pihak. Jika proses mediasi yang dijalani oleh para pihak menghasilkan kesepakatan, dengan perantaraan Ketua Pengadilan Negeri mengajukan kesepakataan damai tersebut ke majelis hakim pemeriksa perkara di tingkat banding, kasasi atau peninjauan kembali. Sebelum diajukan kesepakatan damai tersebut akan diteliti oleh Ketua Pengadilan Negeri atau hakim yang diperintahkan oleh Ketua. Dan seandainya pihak yang berperkara berkeinginan kesepakatan damai tersebut dikuatkan dalam bentuk akta perdamaian maka berkas perkara beserta hasil kesepakatan akan dikirimkan ke pengadilan tingkat banding atau MA.

Masih adanya peluang bagi para pihak melakukan proses mediasi di tingkat upaya hukum akan menimbulkan persoalan jika dikaitkan dengan Hukum Acara Perdata yang berlaku, karena pada tingkat upaya hukum telah ada sebuah putusan dari institusi peradilan yang menilai gugatan maupun pembuktian dalam perkara tersebut dan sudah ada pertimbangan hakim dalam memutus perkara tersebut. Proses pemeriksaan di 
persidangan sebagai dasar pertimbangan hakim dalam mengambil keputusan terhadap perkara yang diajukan upaya hukum tersebut telah dilakukan oleh hakim/majelis hakim. Sementara proses peradilan perdata yang didasarkan pada ketentuan pasal $130 \mathrm{HIR} / 154$ $\mathrm{RBg}$, hanya mengenal upaya perdamaian yang wajib dilakukan oleh hakim kepada para pihak pada saat sidang pertama kehadiran kedua belah pihak. Walaupun proses perdamaiannya telah gagal, Hakim Pemeriksa Perkara tetap berkewajiban untuk terus mendorong para pihak agar dapat menyelesaikan perkaranya secara damai. Kewajiban yang diberikan undang-undang kepada Hakim Pemeriksa Perkara untuk mengupayakan perdamaian berlangsung sejak persidangan dimulai sampai sebelum putusan perkara tersebut diucapkan.

Mediasi merupakan penyelesaian sengketa alternatif yang keberadaan prosesnya berada di luar pengadilan. Akan tetapi dengan Perma No. 1/2008 diintegrasikan ke dalam sistem acara peradilan perdata, sehingga menimbulkan kerancuan dari aspek yuridisnya. Inkonsistensinya juga dapat dilihat dari ketentuan pasal 18 ayat (3) yang menentukan bahwa pada setiap perkara yang masuk ke pengadilan, hakim pemeriksa perkara berkewajiban untuk mengusahakan perdamaian sampai pada tahap sebelum hakim menjatuhkan putusan. Hal ini menandakan bahwa perdamaian hanya boleh dilakukan sebelum hakim menjatuhkan putusannya. Pengertian juga sejalan dengan pendapat yang dikemukan oleh Peter d' Ambrumenil yang mengemukakan pendapatnya bahwa, "The decision to go to mediation maybe taken at any time from the case began until a judge hands down a ruling". 8

Pengaturan Perma No. 1/2008 yang masih memberikan peluang terhadap proses mediasi di tingkat upaya hukum dimana substansi perkara yang dijadikan pokok sengketa oleh para pihak telah mendapat penilaian, pertimbangan dan putusan dari pejabat peradilan/negara yang bertugas dalam kelembagaan negara (pengadilan) yang mempunyai kewenangan sebagai lembaga pemutus (ajudikatif) dalam setiap penyelesaian sengketa kembali diadakan perundingan untuk mencapai kesepakatan damai hal ini mempengaruhi bargaining position para pihak berperkara untuk melakukan re-mediasi sudah berubah, jika seandainya proses mediasi untuk mencapai kesepakataan damai ditempuh sebelum adanya putusan terhadap pokok persoalan yang diminta untuk didamaikan dibandingkan dengan proses mediasi yang ditempuh setelah adanya putusan.

Pengadilan sebagai pelaksana

\footnotetext{
${ }^{8}$ Peter d'Ambrumenil, 1997. Mediation and Arbitration, Cavendish Publishing Limited, Great Britain, p. 41.
} 
kekuasaan kehakiman dan mengemban atau melaksanakan penegakan hukum didasari atas peraturan peundang-undangan yang merupakan suatu sistem yang dijiwai oleh beberapa asas mempunyai wewenang untuk mengadili tentang hak dan kewajiban menurut hukum. Melalui kewenangan tersebut pengadilan-lah yang akan memberi isi dan makna kekuatan norma-norma hukum suatu undang-undang dan peraturan hukum lainnya di dalam penerapan hukum terhadap suatu perkara sehingga apa yang diputuskan oleh hakim itulah yang merupakan hukum yang senyatanya, konsekuensinya masyarakat pencari keadilan harus patuh kepada putusan hukum tersebut, walaupun masih dimungkinkan adanya perlawanan terhadap putusan tersebut, dengan mengajukan perlawanan terhadap putusan tersebut. Perdamaian bisa dilaksanakan di Pengadilan Tinggi bila ia menggelar pemeriksaan tambahan. Pengadilan Tinggi dalam hal ini sama kedudukannya dengan Pengadilan Negeri sebagai judex factie. Hal ini tidak berlaku pada kasasi di MA. Di dalam praktek untuk tingkat kasasi, MA tidak menggelar pemeriksaan berkas perkara, MA hanya memeriksa apakah Pengadilan Negeri atau Pengadilan Tinggi sudah benar dalam menerapkan hukum, ataukah ada putusan pengadilan yang bertentangan dengan atau melanggar undang-undang atau peraturan hukum yang berlaku.
Perma No. 1/2008 yang kedudukannya lebih rendah dari $\mathrm{HIR} / \mathrm{RBg}$ (Undang-undang) dalam substansi materi yang dimuat telah merubah pandangan dalam menerapkan aturan dari ketentuan $\mathrm{HIR} / \mathrm{RBg}$. Substansi peraturan tersebut dapat dilihat dari pasal 21 dan pasal 22 yang mengatur tentang Perdamaian di Tingkat Banding, Kasasi dan Peninjauan Kembali, pengaturan ini melampui apa yang secara tegas diatur oleh undang-undang (HIR/RBg) yang hanya mengijinkan perdamaian dilakukan sebelum pemeriksaan perkara dimulai dan/atau anjuran berdamai ditawarkan oleh hakim kepada pihak yang berperkara sebelum hakim membacakan putusannya. Perma sebagai peraturan yang secara hierarki berada di bawah undang-undang (HIR/RBg) tidak dibenarkan substansi materinya/materi yang diaturnya melampui materi yang diatur oleh peraturan yang lebih tinggi.

Dalam sistem tertib hukum, validitas peraturan yang lebih rendah akan didasarkan dari peraturan yang lebih tinggi demikian juga dengan substansi yang diaturnya. Berdasarkan asas "lex superior derogat legi inferior", peraturan yang lebih tinggi tingkatannya akan menyampingkan peraturan yang lebih rendah sehingga dapat dikatakan peraturan inferior tidak boleh bertentangan atau melampui pengaturan substansi materi superior, suatu norma hukum akan berkekuatan hukum dan mengikat jika 
penentuannya didasarkan pada ketentuan norma yang lebih tinggi tingkatannya. Demikian juga dengan asas "lex specialis derogat legi generali", tidak dapat diberlakukan karena Perma No. 1/2008 hanyalah peraturan pelaksana untuk menjalankan ketentuan hukum acara perdata $(\mathrm{HIR} / \mathrm{RBg})$ dan mendapatkan delegasi dari undang-undang sehingga kedudukan Perma tidaklah sama dengan undang-undang, jadi Perma No. 1/2008 bukanlah produk hukum yang bersifat khusus dari $\mathrm{HIR} / \mathrm{RBg}$. Berdasarkan logika berpikir tersebut dapat dikatakan bahwa Perma No. 1/2008 belum mempunyai landasan yuridis/kekuatan hukum untuk mengatur pengintegrasian mediasi ke dalam acara pengadilan khususnya mediasi di tingkat upaya hukum.

\section{SIMPULAN DAN SARAN}

\section{Kesimpulan}

Perkara yang sudah diputus oleh pengadilan tidak dapat dimediasi kembali. Proses mediasi yang dilaksanakan pada tingkat upaya hukum berdasarkan ketentuan pasal 21 ayat (1) Perma No. 1/2008 bertentangan dengan undang-undang khususnya ketentuan pasal 130 HIR/154 RBg. Perma sebagai peraturan yang berada di bawah undang-undang ( $\mathrm{HIR} / \mathrm{RBg}$ ) tidak dibenarkan substansi materi yang diaturnya melampui materi yang diatur oleh peraturan yang lebih tinggi. Perma No. 1/2008 belum dapat dijadikan landasan yuridis untuk mengatur pengintegrasian mediasi ke dalam acara pengadilan khususnya mediasi di tingkat upaya hukum karena asas lex superior derogat legi inferior dan asas lex specialis derogat legi generali tidak terpenuhi.

\section{S a r a n}

Agar tidak menimbulkan kerancuan dari aspek yuridis, MA sebaiknya me-revisi substansi Perma No. 1/2008 khususnya hal yang berkaitan dengan mediasi ditingkat upaya hukum. Di dalam me-revisi Perma tersebut agar diperhatikan juga mengenai aspek tertib hukumnya supaya pengintegrasian mediasi ke dalam acara pengadilan oleh suatu peraturan dapat memenuhi asas, syarat serta pembentukan peraturan perundang-undangan yang berlaku.

\section{DAFTAR PUSTAKA}

Abbas, Syahrizal, 2011, Mediasi: Dalam Hukum Syariah, Hukum Adat dan Hukum Nasional, Kencana Pradana Media Group, Jakarta.

Andurrasyid, Priyatna, 2002, Abitrase dan Alternatif Penyelesaian Sengketa, Suatu Pengantar, Fikahati Aneska, Jakarta.

Asshiddiqie, Jimly dan Safa'at, Ali, 2006, Teori Hans Kelsen Tentang Hukum, Sekretariat Jendral \& Kepaniteraan Mahkamah Konstitusi RI, Jakarta. 
Boulle, Laurence, 2005, Mediation: Principles Process Practice, LexisNexis Butterworths, Australia.

Bush, Robert A. Baruch and Folger, Joseph P., 2005, The Promise of Mediation, The Transformatuve Approach to Conflict, A Wiley Imprint, San Fransisco.

D’Ambrumenil, Peter. 1997, Mediation and Arbitration, Cavendish Publishing Limited, Great Briatin.

Fuady, Munir, 2000, Arbitrase Nasional, Alternatif Penyelesaian Sengketa Bisnis, Citra Adithya Bakti, Bandung.

Haynes, John Michael, Haynes, Gretchen L. and Fong, Larry Sun, 2004, Mediation, Positive Conflict Management, State University of New York Press, New York.

Marzuki, Peter Mahmud, 2010, Penelitian Hukum, Kencana Prenada Media Group, Jakarta.

Sukadana, I Made, 2012, Mediasi Peradilan, Mediasi Dalam Sistem Peradilan Perdata Indonesia Dalam Rangka Mewujudkan Proses Peradilan Yang Sederhana, Cepat dan Biaya Ringan, Prestasi Pustaka, Jakarta.

Tim Penyusun Pusat Bahasa, 2008, Kamus Bahasa Indonesia, Departemen Pendidikan Nasional, Jakarta.
Witanto, Darmoko Yuti, 2011, Hukum Acara Mediasi, Dalam Perkara Perdata di Lingkungan Peradilan Umum dan Peradilan Agama Menurut Perma No. 1 Tahun 2008 tentang Prosedur Mediasi di Pengadilan, Alfabeta, Bandung.

\section{Peraturan Perundang-undangan}

Undang-undang Nomor 30 Tahun 1999 tentang Arbitrase dan Alternatif Penyelesaian Sengketa.

Undang-undang Nomor 3 Tahun 2009 tentang Perubahan Kedua Atas Undang-undang Nomor 14 Tahun 1985 tentang Mahkamah Agung.

Undang-undang Nomor 48 Tahun 2009 tentang Kekuasaaan Kehakiman.

Undang-undang Nomor 12 Tahun 2011 tentang Pembentukan Peraturan Perundang-undangan.

HIR (Herziene Indonesische Reglement) Stbl. 1941 Nomor 44;

R.Bg (Rechtsreglement Voor de Buitengewesten) Stbl. 1927 Nomor 227;

Kitab Undang-Undang Hukum Perdata (KUHPerdata).

Peraturan Mahkamah Agung Republik Indonesia Nomor 1 Tahun 2008 tentang Prossedur Mediasi di Pengadilan. 
